\title{
Challenges of Reform Tools Implementation: The Case of Business Process Reengineering and Balanced Score Card in Diredawa City Administration ,Ethiopia
}

\author{
Abiy Serawitu \\ Dire Dawa Management and Kaizen Institute, Dire Dawa, Ethiopia
}

\begin{abstract}
The reform tools like BPR and BSC have been implemented in the city administration since about the last ten years .As a result of the implementation, the following reasons are frequent and worth drown for the unsuccessful implementation of change tools accordingly .Among others; include , Lack of leadership commitment , high turnover of office holders, lack of skills of coaching and designing change tools , lack of resource, inefficient skills for communicating the tools ,adopting the study of other regions as it is ,lack of incentives for champions, faulty implementation approach (not using change management tools), absence of implementation manuals, not adhere to change management models, lack of deep rooted skills and knowledge to implement the change tools and absence of conducting performance appraisal respectively.
\end{abstract}

Keywords: BPR and BSC implementation

DOI: $10.7176 / \mathrm{JAAS} / 66-03$

Publication date:July $31^{\text {st }} 2020$

\section{Introduction}

Radica Change is foreseeable in the life of an organization. In today's world, most of the organizations are facing a dynamic and changing of business situation. They should either change or pass away, there is no other third alternative. Organizations that learn and cope with change will succeed and others who fail to do so will be wiped out. According to Ansarian, M. (2014), the major forces which make changes not only necessarily but inevitable are technological, economic, political, social, legal, international and labor market environments

In much uncomplicated words, we can say that radical change means the shift of status quo to the desired state or making things different. "The term change refers to unlearn the past learn of the future."

Here are a number of factors both internal and external which affect organizational functioning. Any change in these factors necessitates changes in an organization. The more important factors are as follows according to Kotter(2002):

External Forces are forces come in outside the organization .Every organization exists in some context; no organization is an isolated in itself. Each must continually interconnect with other organizations and individuals. the customer's shareholders, government and many more. every organization has goals and responsibilities related to each other in the environment. The present day environment is dynamic and will keep on to be dynamic. Changes in social, political, economic, technology and legal environment forces an organization to alter themselves. Such changes may result in organizational changes like major functions of production and service process .In order to survive in the changing environment, organization must change.

Internal Forces are pressure for change within the organization. It is not only the changes in external factors, which may require organizational changes; any change in organization's internal factors may also demand changes. Such a change is required because of for new strategies and goals of an organization, for new technologies (labor /capital intensive), for installing new employee outlook and behaviors for the desired change, Poor efficiency, poor work flows and lack of innovation and the need for higher profit.: By Rick Maurer, book on "beyond the wall of resistance, 2018 " \&"why $70 \%$ of changes fail “

\subsection{Statement of the Problem}

The history of contemporary government bureaucracy is a current phenomenon in Ethiopia The inefficiency coupled with awkward and distracted organizational and ideological setups visibly characterized Ethiopian civil service machineries. From its inception to maturity the civil service in Ethiopia had the orientation to serve attention of rulers than achieving public expectations and imaginings. That resulted in political pressure that gave to the birth of mediocre civil service. Predominantly the direct political motives by the consecutive governments led to deterioration of public trust on the civil-servant in particular and government machineries in general.

According Mengesha and Common (2007) as mentioned, a number of reform programs have been taken place in Ethiopia in different times. Under the existing government, two key reforms have been undertaken. The first was the Civil Service Reform Program (CSRP) (1996-2000) and the second one, the Public Sector Capacity Building Support Program (PSCAP) (2001-present)). Key important landmark was taken in 1997 by developing and putting in action the national capacity building program in reply to improve the weak system of administration 
in public service delivery (Ministry of Civil Service, 2013). The CSRP seek to build a fair, transparent, efficient, effective and ethical Civil Service, primarily by creating enabling legislation, developing favorable operating systems and the capacities of civil servants through suitable training.

To this end, the following five main reform sub-programs were carried out: expenditure management and control reform; human resource management reform; public service delivery reform; management system reform; and civil service ethics reform (Mengesha and Common 2007; Tilaye 2007). Based on lessons learnt from the first CSRP reform efforts, the major objective of the second reform program (the PSCAP) was to get better service delivery and organizational effectiveness through the strengthening of working systems, technologies, and the knowledge and skills of civil service employees (Tilaye 2007)

In connection to his, much policy and implementation concentration was given to Business Process Reengineering (BPR) and Balanced Score Card (BSC). It has been implemented in all bureaus and other government structures of Dire Dawa administration for a reasonably long period of time. Measuring the performance and learning from the preceding implementation is very critical, identify the major challenges have obtained and which are not and why, and more prominently take corrective measures including recalibrating the BPR to make the implementation of these reforms more effective.. This study will use empirical evaluation techniques to measure the implementation success of the reform tools.

Hence, the purpose of this empirical study is to investigate the success of BPR and BSC implementation on public organizations in Dire Dawa city administration.

\subsection{Objectives of the Study}

The main objective of this study is to examine challenges of change tools implementation in Dtre Dawa city administration.

\subsubsection{Specific objectives of the study}

to examine the major top challenges of change tools (BPR\&BSC) in Dtre Dawa city administration

$>$ to assess the most and the least frequent challenges for the successful implementation of BPR\&BSC

$>$ to recommend solution for future success

\subsection{Research Questions}

$>$ What are the major challenges of reform implementation in the city administration

\section{Literature Review}

\subsection{Concept and Definition of BPR and BSC}

The Balanced Scorecard (BSC)was developed by two persons, Robert Kaplan, an accounting professor at Harvard University, and David Norton, also consultant from the Boston area. In 1990 Kaplan and Norton lead a research study of a dozen companies investigating new methods of performance measurement.

Balanced scorecard is a carefully preferred set of quantifiable measures resulting from an organization's strategy. The measures selected for the Scorecard signify a tool for leaders to use in communicating to employees and external stakeholders the outcomes and performance drivers by which the organization will attain its mission and strategic objectives. The Balanced Scorecard is a management tool that gives stakeholders with a all-inclusive measure of how the organization is progressing towards the achievement of its strategic goals. It is a restricted framework for becoming more strategy focused A Balanced Scorecard is developed based on four perspectives:

- $\quad$ Customer perspective: to attain our vision, what customer needs must we serve?

- $\quad$ Financial perspective : to satisfy our organizational elements, what financial \& regulatory objectives

- Internal Process perspective: To satisfy our customers and stakeholders, at what point we must exel

- $\quad$ Learning and Growth perspective: To achieve our goals, how must we learn, communicate and grow?

Business process reengineering (BPR) is the most widely recognized and applied change management tool and practice. Globalization is characterized by dynamic change in knowledge and competition. It is forcing companies to initiate change in production and service delivery. As a result of traditional approaches and management practices required to be replaced with innovative and adaptive modern way of doing jobs and technologies that promote in producing competent products and delivering services in line with market and global needs. Businesses that do not change their approach cannot live on firm competition and soon get vanished. therefore, public and business organizations in answer to the global and organizational environment changes are implementing different change management tools and practices such as Business Process Reengineering (BPR) (Habib and Shah, 2013).

Business Process Reengineering is not a mysterious word to the business world. It has been more than two decades since it was first introduced as change management tool among American business enterprises. It was Hammer (1990) who first introduced the idea of BPR and is considered as a father of BPR. originally BPR was adopted by US private business enterprises in early 1990s to convey radical change in the business process in a substitution of Total Quality Management (TQM) philosophy (Hammer and Stanton, 1995). BPR is considered to 
be an innovative change tool or approach that improves organizational performance and processes from incremental orientation to a new radical approach of change management.

Hammer and Champy (1993), was explained the term reengineering as the fundamental rethinking and radical redesign of business process to achieve dramatic improvement in critical modern measures of performance, quality ,such as cost, service and speed. While Davenport and Short (1990) put it as a process of analysis and workflow redesign in an organization. moreover, different writer gave different theoretical and practical definitions to BPR (see Sorunke and Nasir, 2016).

\section{2., BPR Success and Failure Factors: a review of empirical studies}

Business process reengineering (BPR) implementation efforts have studies locally and internationally. nevertheless, most of the empirical studies were mostly focused on the private sector. The focus on public sector in terms of implementation and examination for impact seems a recent endeavor. A study by Guimaraes and Bond (1998) pointed out that the success rate of BPR implementation had shown diverse result of success and failure. Although BPR has brought noteworthy change in improving productivity and application of IT, it also was time consuming and too troublesome that produce moderate change than radical organizational transformations. above and beyond, other studies on BPR implementation process identified restrictions associated with setting aside social and human elements. More emphasis was found to be given to methodological process redesign over attitudinal and behavioral changes (Sorunke and Nasir, 2016).

In assessment of the best practices of Mansar and Reijer (2007) found different implication of BPR on cost, quality, flexibility, and time. Efforts to group job parallel or to carry simultaneously out were positively contributing to time reduction in the process but it was costly due to the need to introduce new technology that goes with the new process. additional, an article by Setegn et al (2013) assessing the impact of BPR in public sector in Ethiopia pointed out that implementing BPR optimistically brought change concerning behavior, skill, participation, team work and management systems. though, the change was seeming as incremental other than radical one. In addition to this, a study conducted by Abdurazak (2010) in relation to BPR implication on employees exited that BPR has contributed positive role in empowering employees in decision making through engagement and participation as well as career development. On the other hand both studies mentioned absence of new reward system that goes with the reengineered organizational process and structure.

Success is not guaranteed in any change effort. There is a possibility for failure. This is true with BRP. According to the developers of the reform tool, it is estimated that 70 percent of attempts to implement BPR results in failure. in contrast, study conducted by Al-Mashari, Irani and Zair (2001) found out that more than 50 percent success rate. The same study revealed that a survey from Scotland indicated that there was 6 percent failure rate in BPR implementation. Success and failure depends on soft and hard factors. With this in mind, thus, it necessitates reviewing various theoretical and empirical literatures to identify factors that contribute to success and failure (Al-Mashari and Zairi, 1999).

\section{RESEARCH METHODOLOGY}

\subsection{Research Design}

The research used descriptive and Qualitative research approaches.

\subsection{Methods and source of Data Collection}

The study employs secondary data sources and FGD with customers and respondents having 10 key informants in each separate group. The secondary data was collected from federal and regional reports; manuals and quarterly and yearly reform review documents (2009-2018).Two FGD were conducted with key informants organized from customers and employees separately. Document reviewing cheek list and unstructured questioners were prepared for FGD.

Document review on (Report and amended BPR \&BSC training materials), review on the study conducted by Haromaya University on The Impacts of Business Process Reengineering (BPR) and Balanced Score Card (BSC), relevant reports, documents and other related empirical articles studied by different scholars

\subsection{Method Data Analysis}

Systematic and empirical meta-analysis techniques

\section{Results and Discussion}

\subsection{Document Review}

Since about the last 10 years in Dire dawa administration the change tools like BPRand BSC were implemented in all government organizations. As a result of report review collected from Diredawa administration civil service bureau and federal from (2009-2018), BPR \&BSC amended training material prepared by ministry of public service\& human resource development (2009) and FGD , the change implementation status are not as such 
successful as expected .Based on report and amended training material analysis the following reasons are worth drown for the unsuccessful rreform implementation of the aforementioned change tools. Among others; include , Lack of leadership commitment, lack of skills of coaching and designing, lack of resource, inefficient skills for communicating the tools, replicating the study of other regions as it is ,lack of incentives for champions, Faulty Implementation Approach (not using change management tools) , lack of implementation manuals , lack of plan for managing resistance, lack of deep rooted skills and knowledge to implement the tools, fail to understanding the vision and mission of the organization(95\%), absence of integrating incentives with the strategy (75\%), absence of integrating budgets with the strategy $(60 \%)$, more than $85 \%$ of the top management discuss less than an hour on the strategic issues

Likewise, The study conducted by Haromaya University on The Impacts of Business Process Reengineering (BPR) and Balanced Score Card (BSC) on Performances of Public organizations: The Case of Dire Dawa Administration Council (2017) revealed that implementation stages of BSC (cascading, automation and evaluation) were with significant gaps .absence of preparing The quarterly, bi-annual and annual reports in BSC format, The implementation of BPR is not radical, leaders are focused on routine activities than strategic one, absence of integration on the implementation of the tools, lack of merit based allocation of change and good governance coordinators ,high employees and managers turn over, not timely reshaping BPR and BSC documents .

\subsection{Focus Group Discussion (FGD)}

To summarize the allover FGD both employees and customers were discussed whether they think that the reform was successful in achieving the intended outcomes. The majority of FGD of customers feel that the reform was successful as compared to employees. It is surprising that the service providers feel less confident than their service users on the success of the reform tools implementation.

Both FGD also discussed the major challenges of BPR and BSC implementation. As a result of which the following major challenges are worth drawn:

- Lack of leadership commitment

- High turnover of top management

- Absence of incentive for champions

- Absence of involving employees in the reform process

- $\quad$ Lack of closer monitoring, evaluating and coaching

- $\quad$ Failure to use change management models

\section{Conclusions and Recommendations}

\subsection{Conclusions}

This research was conducted in Diredawa city administration with the prime intent of critically assessing the major challenges of BPR and BSC implementation. Based on the objectives and findings of the study, the following conclusions are worth drawn:

This paper tries a systematic and meta-analysis review of various empirical literatures along with the findings of the study, explored the most top frequently mentioned reasons for change tools implementation failures. These challenges to change tools implementation were grouped respectively as follows: strategic barriers, human resources barriers, structural barriers, contextual barriers, and procedural barriers. According to the study, Strategic inhibiters are identified as first most significant barriers to the change tools implementation practices in the city administration. These barriers are mainly related to management and leadership of the organization. Inhibitors like: lack of leadership commitment and involvement, absence of coaching, monitoring and evaluation ; poor management, high office holders turnover, lack of strategic planning practice (BSC) \& absence of conducting performance based evaluation are grouped in this category .Human resource problems were the second most frequently mentioned reason for change tools implementation failure followed by strategic problems. The human resources barriers are those obstacles that are related to the human factor such as staff shortage, absence of employee involvement and participation in the change endeavors, resistance to the change, fear of losing job, fear of unknown, high employee turnover and inadequate human resource management practices.. The structural obstacles are related to the structure, systems and resources required for implementing the change (e.g., inappropriate organizational structure, lack of resources and information system).Contextual barriers includes , among others: inappropriate organizational culture, Lack of team orientation, lack of employee trust in senior management, Problems in solving fixed mindset, ineffective communication. Procedural barriers also includes: lack of expertise knowledge and kill to implement the change, fail to follow appropriate change management model, lack of customer focus services, Bureaucratic cumbersome.

\subsection{Recommendations}

Based on the conclusions reached by this study, the following recommendations have been forwarded. 
- drawing systems of coaching, monitoring and evaluation system as long as the change is being capture

- office heads should improve periodic and need-based recalibration of their structures with full participation of implementers especially the lower level units who were denied full participation in the first phase of the reform implementation. .

- $\quad$ Each office holder should evidently understand the process, strategic issues as well as objectives with the targets intended to achieve, and other strategic management and reform related issues. This can be easily done by reading the BPR documents, and strategic plans of the bureau in question.

- office holder should be chiefly engaged in strategic issues rather than the unplanned ones. Frequent meetings of officials and employees have to be reduced and managed properly to save time for better service provision.

- $\quad$ There should be permanent briefing and awareness creation efforts for employees to understand that all the change tools are interconnected by their nature so that these would not be considered as additional burden introduced to make people busy.

- Mechanisms should be devised to enhance overall process and system automation in order to reduce the paper works of BSC and delays in BSC implementation.

- $\quad$ The quarterly, bi-annual and annual reports of bureaus should be prepared in BSC format , and this should be assisted by reform coordinators

- Clear guideline should be developed and made clear for employees to implement pocket cascading..

- The administration and individual offices at different levels should occasionally evaluate their status in implementing the change tools and the resulting outcomes in achieving the organizational mission. In doing so, the missing elements should be continuously improved so that the full impact of the reform can be realized and radical changes can be achieved.

- The accomplishment of change tools particularly BPR and BSC should not only be left for the reform coordinators. It should be embodied in the main structure and every office holders or head should follow up, evaluate and support his subordinates about the reform implementations. This is the main mechanism through which change tools are consistently implemented and getting assisted by them becomes a culture.

\section{Reference}

Abebe A. et al. (2017) .The Impacts of Business Process Reengineering (BPR) and Balanced Score Card (BSC) on Performances of Public Organizations: The Case of Dire Dawa Administration Council

Adebabay Abay and Stephen J. Perkins. (2010). Employee Capacity Building and Performance in Ethiopian Public Services, Ministry of Capacity Building, Ethiopia

Al-Mashari, Majed, Zahir Irani and Mohamed Zair. (2001). Business Process Reengineering: A Survey of International Experience, Business Process Management Journal Vol. 7 No. 7 Pp. 437-455

Al-Mashari, Majed and Zairi, Mohamed. (1999). BPR Implementation Process: An Analysis of Key Success and Failure Factors, Business Process Management Journal, Vol. 5 No. 1, pp. 87-112

Guimaraes, Tor And Wendi Bond. (1998). Empirically Assessing The Impact Of Business Process Reengineering On Manufacturing Firms, Gestão \& Produção V.3, N.1, P. 8-32

Habib, Muhammad Nauman.(2013). Understanding Critical Success and Failure Factors of Business Process Reengineering,International Review of Management and Business Research, March, Vol. 2 Issue.1

Hammer M. (1990). Reengineering Work: Don’t Automatic Obliterate. Harvard Business

Hammer, M., \& Champy, J. (1993). Reengineering the Corporation, Harvard Business Review Journal

Kaplan, R. and Norton, D. (1996) The Balanced Scorecard Boston, MA: Harvard Business School Press

Kotter(2002.Change Management Extra, Elsevier Ltd, Italy Fitzgerald, B. and Murphy, C. (1996) Business Process Reengineering: The Creation and Implementation

Mansar, S. Limam and Reijers, H.A. (2007). Best practices in business process redesign: use and impact, Business Process Management Journal, Vol. 13 No. 2, pp. 193-213

Marcella Bremer(2014). Business process re-engineering. Management Services, Vol.41, pp.34-6.

Sorunke, Oluwatosin and Nasir, Ameen. (2016). Critical Success Factors of Business Process Reengineering, Case Study: IBM, International Journal of Thesis Projects and Dissertations (IJTPD) Vol. 4, Issue 2, pp: (1-48), April - June Stanley Thomas Ltd, Cheltenham

Steve Strauss (2017. Reengineering Organizations: A Critical Appraisal, Personnel Review Vol. 24 No.1

Tilaye Kassahun . (2007). 'Civil service reform program', in Proceedings of the first national conference on the achievements, challenges and prospects of the Civil Service Reform Program Implementation in Ethiopia, Ethiopian Civil Service College, Addis Ababa. 


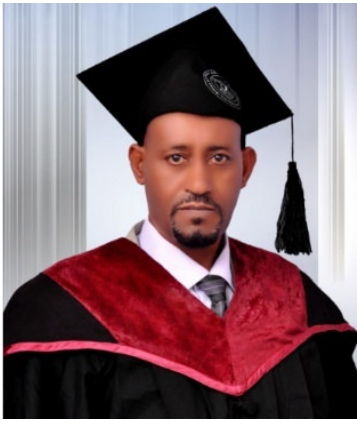

Abiy Serawitu Kassaye

Senior consultant at Dire Dawa Management and Kaizen Instit

(PhD Candidate) 